\title{
WARS WITHOUT END \\ The Political Economy of a Precolonial African State
}

\section{S. P. Reyna}




\section{Contents}

Illustrations

vii

Preface

ix

Chapter I Introduction

\section{PART I A SAVANNA PERIPHERY 13}

$\begin{array}{lll}\text { Chapter } 2 \text { The East-Central Sudan } & 15\end{array}$

Chapter 3 Origins and Other "Impressive Things" 41

\section{PART II THE SUN KINGS' REALM 57}

Chapter 4 The Social Landscape 59

$\begin{array}{lll}\text { Chapter } 5 & \text { Food Producers and Their Households } & 72\end{array}$

Chapter 6 The Sun King and His Court 92

$\begin{array}{lll}\text { Chapter } 7 & \text { Revenue Collection and Allocation } & 119\end{array}$

$\begin{array}{llll}\text { Chapter } 8 & \text { Warfare } & 135\end{array}$

PART III PREDATORY ACCUMULATION 149

Chapter 9 Predatory Accumulation in Fields of Empire 151

$\begin{array}{lll}\text { Chapter } 10 \text { Epilogue } & 165\end{array}$

$\begin{array}{ll}\text { Appendix: Sources } & 167\end{array}$

$\begin{array}{ll}\text { Notes } & 173\end{array}$

$\begin{array}{ll}\text { References } & 185\end{array}$

$\begin{array}{ll}\text { Index } & 197\end{array}$ 


\section{Illustrations}

Map 1.1 The Setting of the East-Central Sudan 2

Map 2.1 East-Central Sudanic Bioclimatic Zones 16

Map $2.2 \quad$ East-Central Sudanic Languages 21

$\begin{array}{lll}\text { Map } 3.1 \quad \text { Bagirmi } & 42\end{array}$

$\begin{array}{llr}\text { Figure 3.1 Fluctuations in Lake Chad } & 47\end{array}$

$\begin{array}{lll}\text { Figure 8.1 Reproduction of the Bagirmi State } & 148\end{array}$

Table 2.1 East-Central Sudanic Languages 19

Table 3.1 Rulers of Bagirmi 52

Table 6.1 The Mbang and His Court 107

Table 7.1 Estimated Bagirmi Taxes during the Late Nineteenth Century 129

Table 7.2 Revenues of Bagirmi and Wadai during the Late Nineteenth Century 131 